\title{
Field assessment of the balance between greenhouse gases and ammonia emissions from grassland under various $\mathrm{N}$-management regimes
}

\author{
F Bourdin $^{1,2}$, G Lanigan $^{1}$, R Sakrabani ${ }^{2}$, M Kibblewhite ${ }^{2}$ \\ ${ }^{1}$ Teagasc, Johnstown Castle, Wexford, Ireland, ${ }^{2}$ Cranfield University, Cranfield, Bedfordshire, United Kingdom \\ Email: Frederic.Bourdin@teagasc.ie
}

Introduction Agriculture in Ireland contributes $98 \%$ of ammonia $\left(\mathrm{NH}_{3}\right)$ and $26 \%$ of greenhouse gas (GHG) emissions (CSO, 2008). Manure management is one of the key drivers of these emissions. This study aim at: a) measuring the effect of organic and ammonium fertilizer on $\mathrm{GHG}$ and $\mathrm{NH}_{3}, \mathrm{~b}$ ) investigate the impact of cattle slurry composition on these emissions.

Materials and methods A field-plot experiment $(2 \times 1.5 \mathrm{~m}$ per plot, $\mathrm{n}=3)$ was carried out, with grass-derived and maizederived slurries of high and low dry matter (DM) content. Plots were spread using splash-plate application. In addition, one of the combinations of maize-derived slurry DM content was spread on three additional plots simulating trailing shoe, in order to compare both slurry application techniques. Control plots include no $\mathrm{N}$ fertilization and $60 \mathrm{~kg} \mathrm{~N}^{-1}$ of calcium ammonium nitrate (CAN) fertilization. Two treatment applications were carried out in April and July 2009 under contrasting climatic conditions.

Continuous flux measurements were taken after slurry application. Ammonia was measured using a photo-acoustic analyzer (INNOVA 1412 Trace Gas Analyser, INNOVA Instruments, Copenhagen, Denmark) coupled to a dynamic chamber. Carbon dioxide and nitrous oxide were measured using static chambers and an Infra-Red Gas Analyzer $\left(\mathrm{CO}_{2}, \mathrm{PP}\right.$ Systems EGM-4, PP Systems, Hitchin, Herts., UK) or a gas chromatograph $\left(\mathrm{N}_{2} \mathrm{O}\right.$, Varian) for the analysis of the gases. Ancillary data (air and soil temperature, rainfall, soil moisture, soil ammonium and nitrate concentration) were also collected.

Cumulative fluxes were calculated for the first week following fertiliser application (Figure 1). Background fluxes (control plots) were subtracted from fluxes calculated for treatments plots. These treatments were compared using ANOVA with slurry dry matter and slurry types as main factors.

Results The indirect effect of ammonia volatilisation on $\mathrm{N}_{2} \mathrm{O}$ emissions were calculated using IPCC default factors (IPCC, 2007). These emissions were highest for high DM grass-based slurry in July under warm dry conditions (Figure 1a). Emissions were significantly lower when slurry was spread in April and also for trailing shoe spread slurry in July. Reducing slurry DM content substantially lowered direct nitrous oxide emissions in spring, but not in summer. Methane emissions were generally low, but increased when slurry was trailing-shoe applied. In term of splash-plate application, maize slurry (high DM) emitted significantly $(\mathrm{p}<0.05)$ more methane than grass slurry. C mineralisation was substantial and increased on slurry application (Figure 1b). This priming effect on soil respiration over the measurement period varied from $400 \mathrm{~kg} \mathrm{CO}_{2}$ ha-1 for grass slurry to $2000 \mathrm{~kg} \mathrm{CO}_{2} \mathrm{ha}^{-1}$ for maize slurry.
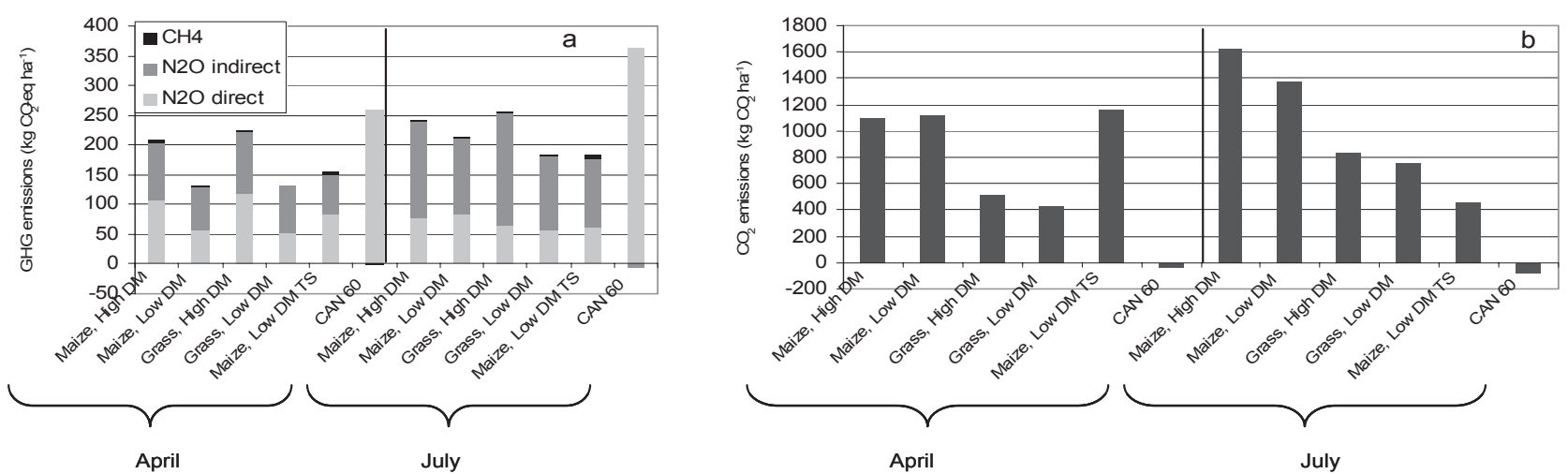

Figure 1 a) Cumulative GHG fluxes of trace gases $\left(\mathrm{kg} \mathrm{CO}_{2}\right.$ eq ha $\left.{ }^{-1}\right)$, and b) $\mathrm{CO}_{2}$ emissions rates in April and June 2009, for the seven days following slurry application. Background emissions were subtracted from those calculated for treatments. Indirect $\mathrm{N}_{2} \mathrm{O}$ emissions were calculated using the IPCC default value of $1 \%$ of $\mathrm{NH}_{3}$ reemitted in the atmosphere as $\mathrm{N}_{2} \mathrm{O}$ (TS: trailing-shoe application).

Conclusion In terms of trace gases, indirect $\mathrm{N}_{2} \mathrm{O}$ emissions sourced from ammonia losses comprised the largest proportion of landspreading emissions when slurry was spread in warm conditions. Direct nitrous oxide emissions were higher in spring and also higher for trailing shoe. There was also a substantial 'priming effect' in terms of $\mathrm{C}$ mineralisation when organic fertiliser was applied and these $\mathrm{CO}_{2}$ emissions dwarfed other emissions over the measurement period.

Acknowledgements This work is funded by the Walsh Fellowship Scheme.

\section{References}

CSO 2008. Greenhouse Gas and Acid Rain Precursor Accounts for Ireland. Dublin, Central Statistic Office (CSO). IPCC 2007. Climate Change 2007, The Physical Science Basis - Contribution of Working Group I to the Fourth Assessment Report of the Intergovernemental Panel on Climate Change (IPCC), Cambridge, Cambridge University Press. 